\title{
The Self Employed Women, Women Entrepreneurs And Work
}

\author{
Nasreen Aslam Shah \\ Women's Studies \\ University of Karachi
Muhammad Nadeemullah
\&
Muhammad Faisal Zia
Department of Social Work
University of Karachi
Shamim Soomro
Department of Social Work
University of Sindh, Jamshoro

\begin{abstract}
This study highlights foundation that women encompass - inside their houses as unpaid family work, as wage-earners to be found at the lowest position of income generating work and as care-givers. Here few questions could come to one's mind that what is the extent of women's responsiveness regarding work, of everyday jobs, of class and role? How do they differentiate themselves being dominated under weight of various roles? Or are they doubly demoralized by the patriarchal system? How this amalgamation of professions is made possible? The study illustrates field research seeking answers to these questions. The interviewing schedule created for this research included questions that aimed at obtaining personal data about the respondents, such as age, educational attainment, marital status, number of children, typology of work, etc. The data drawn from sample shows ability of self employed working women to balance their income generating work with their communal roles of food preparation, cleaning, caring, parenting and other domestic chores. Therefore, the vision that this research explores, deny the imagined characteristics of women as a male responsibility. These self employed women indeed are heads of their households. This timely study invites all concerned authorities, policy makers and governmental institutions to recognize this reality and consequently plan for the upcoming decades.
\end{abstract}

\section{تلخيصِ مقال}

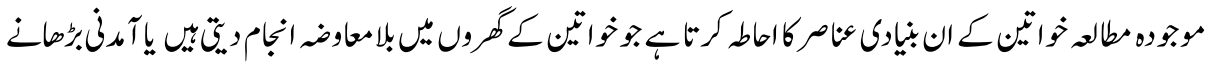

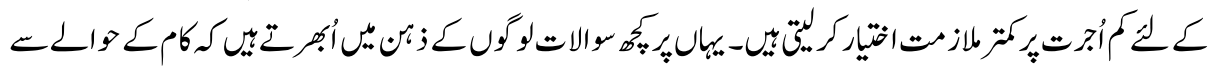

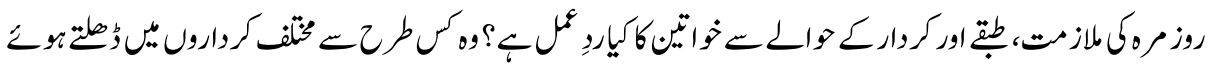

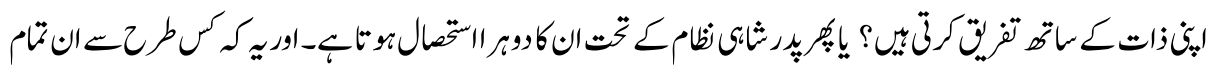

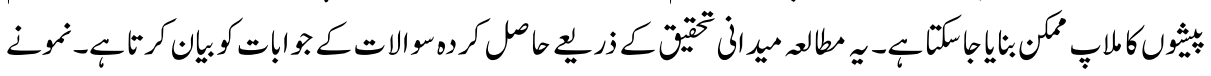

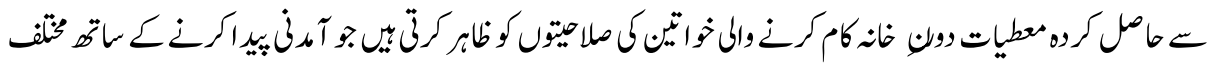

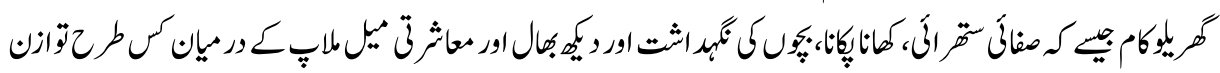
قاكُكرنيهي 
Key Words: Self employed women workers, working conditions

\section{Introduction}

The number of businesses owned by women around the world has increased significantly over the past decade. However, women are still hamstrung in their attempts to participate fully in entrepreneurial activities as a result of discriminatory laws, gender blind policies and cultural practices. Notably, research shows that female entrepreneurs find accessing capital, contracts and markets more difficult than their male counterparts. Hence, gender statistics therefore play a crucial role in order to understand the impact of policies, norms and cultural values of the entrepreneurial activities of women and men (Franco, 2002).

The entrepreneurial activities of women vary considerably across sectors. Female entrepreneurs are generally more represented in services than manufacturing and construction. However, the European indicators on female entrepreneurs divided by sector sometimes rely on non-harmonized national data and must be interpreted carefully (Commission of the European Communities. Brussels, 21.11.2001. SEC, 2001).

Microcredit is a financial innovation that is generally considered to have originated with the Grameen Bank in Bangladesh. In that country, it has successfully enabled extremely impoverished people to engage in self-employment projects that allow them to generate an income and, in many cases, begin to build wealth and exit poverty. Due to the success of microcredit, many in the traditional banking industry have begun to realize that these microcredit borrowers should more correctly be categorized as pre-bankable; thus, microcredit is increasingly gaining credibility in the mainstream finance industry, and many traditional large finance organizations are contemplating microcredit projects as a source of future growth, even though almost everyone in larger development organizations discounted the likelihood of success of microcredit when it was begun (Cons , 2008).

According to the report by African Studies Centre 'For women, the development quagmire presents a challenge as to which way a reversal from 'development with women' into 'women with development' can be realized. From the 1990s, microfinance came to be seen as a window of hope by development agencies who largely trail economic development. Such zeal originates from the idea that microfinance can provide for 'killing two birds with one stone'. It can facilitate poverty reduction through improved quality of life on the one hand, and women's empowerment on the other. This means that through microfinance, women can be engaged in the market both for market efficiency gains and for their own gains in challenging hegemonic gender relations. To this end, the donor community, national governments, and other grass root-based development agencies took microfinance high on their agenda' (Lakwo, (2006). 
A region like South Asia, which is already home to a quarter of the world's poor population, can certainly not afford to let globalization further compound the inequalities, already existing here. Moreover, it is said that poverty today has a woman's face. Of the 1.3 billion people living in poverty, 70 percent are women. Women produce a staggering $60 \%$ of all food, run $70 \%$ of small-scale businesses and make up a third of the official labor force - in addition to caring for families and homes (Human Development Report 2004 ) 5. We are witnessing today that poverty is more deep-rooted for women. Exclusion are actively produced and reproduced by specific processes of production and market engagement make it an imperative for us all to address the processes of impoverishment in general and, feminized impoverishment, in particular. Feminization of poverty is a dynamic process of social exclusion and marginalization that operates differentially among women and men, involving discrimination, denial, and violation of human rights leading to deprivation and vulnerability to risks and difficulties for women (Research Study of South Asia Partnership-Pakistan and the Centre for Development Policy Alternatives, 2009).

According to the Human Development Report on South Asia, (2003) the impact of crisis of poverty is particularly sensitive on the most defenseless sections of society that are women and children. The agony of women is intensified as they face social discrimination, gender inequality in the access over fundamental services, employment and income (Hussain, 2003).

In Pakistan, the financial crisis is a demonstration of the relationship between problems of governance, the decay of institutions, and the adverse structure and slow growth of GDP. The essential feature of the problem in the context of economic revival is that the government has severe fiscal constraints to undertaking major initiatives for stimulating the economy or directly attacking poverty (Hussain, 2003).

\section{Women Entrepreneurs/Self Employed Women}

The debate for women engaged with the self employed or microfinance business has been given much attention since last 10 years. Different patriarchal norms hinder the process of development of self employed women in Pakistan.

Amartya Sen in his work Development as Freedom (Sen, 1999) acknowledges the presence of this notable scarcity, poverty, and domination on a global scale. He portrays the picture of the life of the deprived suffering from persistence of poverty and unfulfilled basic needs, occurrence of famines and widespread hunger, infringement of elementary political freedoms as well as basic liberties, widespread neglect of interest and agency of women to our environment and to the sustainability of our economic and social live. 
Gender is one of the organizing principles of Pakistani society. Patriarchal values embedded in local traditions and culture predetermines the social value of gender. An artificial divide between production and reproduction, created by the ideology of sexual division of labor, has placed women in reproductive roles as mothers and wives in the private arena of home and men in a productive role as breadwinners in the public arena. This has led to a low level of resource investment in women by the family and the State. Thus, low investment in women's human capital, compounded by the ideology of purdah (literally "veiled"), negative social biases, and cultural practices; the concept of honor linked with women's sexuality; restrictions on women's mobility; and the internalization of patriarchy by women themselves becomes the basis for gender discrimination and disparities in all spheres of life (Situational Analysis of women in Pakistan-An Overview).

According to a status report, about half of Pakistan's self employed women are women entrepreneurs (Shaeed, 1990).

Mayoux describes women's access to microfinance services have significantly increased over the past two decades. By enhancing women's ability to earn an income, these programmes have the potential to initiate a series of 'virtuous spirals' of economic empowerment and increased well-being for women and their families. For example, high repayment levels by women do not necessarily indicate that they have used loans themselves. Men may take loans from women, or women may choose to invest loans according to men's priorities. Likewise, high demand for loans by women may be a sign of social pressure to access resources for in-laws or husbands rather than an indicator of empowerment. Where women are unable to negotiate changes in intra-household and community gender inequalities they may become dependent on loans to continue in lowpaid occupations with heavier workloads. However, these shortcomings should not discourage microfinance programmes being undertaken. The experience of current innovations in many programmes indicates a range of ways in which contribution to women's empowerment can be increased. Suggestions include the need to provide services to reduce the burden of unpaid domestic work on women including childcare, and to ensure that repayment schedules and interest rates reflect reality of women's economic activities and life cycles (Mayoux, 2006).

Kristina Becker defines informal economy as the free non-formal portion of the market economy that produces goods and services for sale or for other forms of payment identifies four characteristics of informal economy: (Becker, 2004).

$>$ Low entry requirements in terms of capital and professional qualifications.

$>$ A small scale of operations.

$>$ Skills often acquired outside of formal education.

$>$ Labour-intensive methods of production and adapted technology. 
Here I would like to suggest that it's very important to make women empower to provide them stability in the microfinance or self employment sectors. It should be noted that women entrepreneurs are set apart from family labor such as in agriculture and traditional artisan families in the rural areas and small towns of Pakistan. Therefore, women entrepreneurs as meant in this study are basically found in urban slums of Karachi.

\section{Objectives of the Study}

This research was designed with the objective of assessing the role of the self employed women and attempting to seek amplification as to whether women work for survival or whether their work output contributes towards growth and expansion (Beyond Credit).

\section{Review of Literature}

The self employed women is a wide spread term having a cluster of meanings under its name. The term self employment is defined according to culture, politics and in different contexts depending upon the literature or situation given. This paper of mine basically covers the wide range of data taking out a variety of definition for self employment. ILO Study conducted in 2002 states that the term "home based worker" is used to refer to the general category of workers who carry out remunerative work within their homes or in the surrounding grounds (ILO, 2002).

The present conditions of self employed women in Pakistan are the result of major flaws in the process of development. Tasneem Siddiqui highlights these problems as: industrial development without ample development in agriculture, attempting to establish large scale industry without the preceding development of small scale industry, urbanization outpacing industrialization and population growth racing to the lead of increase in employment opportunities (Siddiqui, 2005).

Shalini Sinha in one of her study which was conducted in an Indian background observed that in the past women took on works like dairying, basket and mat making, weaving etc. They do such jobs also for the utilization of the household or for the local market. The speedy rejection of the formal sector which has caused loss of jobs by a large number of workers, Sinha's study disperse this as a factor pushing workers into informal work, including home based (Sinha, 2006).

The position of women in the labour force varies with the level of economic development. Christine Marmen and Chritina Paxon gauge this situation that in poor countries women are mainly engaged in family enterprises issues such as gender gaps in wages and glass ceilings are largely unrelated. Instead, the major concern are how resources are owed to 
women and girls inside their families; whether women are engaged in self-employment face obstacles in access to credit and other factors of production and beside that women have right to inherit or purchase land or own other assets (Mammen, 2000).'

Additionally, a self employed women's association with informal economy auxiliary deprives them from social protection safeguard including work security, health care, retirement benefits and even representation (Home Net South Asian and Institute of Social Studies Trust, 2006). The term 'women workers' has been explained by many theorists which identify the bonding of women with their work. In the light of the argument developed by feminist theorists claims that the working woman wage earner is possibly be more radical than the housewife. This is because women workers are able to identify the reality of wage gaps and therefore know that women's rights do not subsist in practice (Humm, 1989).

The working conditions of self employed women have not been changed since years. They have been caught in the cobweb of poverty and patriarchy which influenced their working conditions both in domestic and public spheres. Mernissi exemplify this situation by making an argument that women had their place as unquestioned collaborators in a revolt that made the mosque as open place and the family unit a temple of debate (Mernissi, 1991).

A study conducted in 1973 by scholars Salahuddin and Shamim, hardly three years after the Dhaka fall deals with the story of dawn-to-dusk resistance by the poor, asset less, nomadic, migrant women who come from the rural areas to work in the city of Dhaka, in the informal sector portrays that almost all of these women were poor and worked under nerve-racking conditions (Salahuddin, 1992).

The Home Net South Asia's Kathmandu Declaration held in the year 2000 revealing the estimate of women working in the informal sector represents that there are over 100 million home based workers around the globe, among them over 50 million home based workers belonged to South Asia ,of whom around 80 per cent are women.'

The report by the UNIFEM on Progress of World Women, 2008-2009 indicates that although the susceptible employment has lessen globally by three percent since 1997 but about 1.5 billion people are still in this class and the shares are larger for women at 51.7 percent. This difference is worse in some regions showing the ratio, i.e. eight out of ten women workers are in vulnerable employment in sub-Saharan Africa and South Asia (UNIFEM, 2009).'

The routine definition of 'work' is defined as waged labour in a formally structured employment relation which is based upon a masculine ideal of 'work'. On the other hand 
the argument made by McDowell is that it is important to note what is regarded as work, is a result of both societal and statistical definitions which have a variety of meanings (Linda, 1999).

In South Asian belt majority of women have to face the triple burden of work. Dr. Anupama Singh analyses this situation by portraying the life of working women in the rural background in one of her book, that everyday chores in which these women are engaged includes, collection of water, fuel, feeding, preservation of kitchen garden, guarding the farmlands, care of dairy animals and their products, domestic house work, all of these together make their relationship very special and close to nature (Singh, 2008).

An economist Yasmeen Mohiuddin, a Pakistani national based in the USA observes that poverty is an issue of both gender and class in South Asia because imbalanced gender relations feminize poverty which results in more poor women than there are poor men, their poverty is more stern, and they face greater difficulties in lifting themselves and their children out of the poverty trap (Mohiuddin, 2006). Due to these uneven gender relations, Mohiuddin state that poor women suffer more from capability scarcity than poor men (Mohiuddin, 2006).

A sociologist describes the working condition of self employed women in his book that the relationship between hours of work and female participation in the labor forces over lifetime. He found that family income has no effect on wife's demand for leisure. The probability of LFP is inversely related to lifetime wealth measures. He concluded that the number of children also affect lifetime labor supply decisions significantly (Naqvi, 2002).

Amal Rassam argued that women of rural back - grounds suffered a rejection in status as they have lost their productive role which they traditionally played in the pre- industrial economy as the goods they produced were replaced by imported or locally produced factory ones (Rassam, 1984).

Sanjay Tiwari and Anshuja Tiwari in their book describe the blockades faced by women entrepreneurs by stating that women have lack of knowledge of the economic environments in which they have to function, lack of skills in assembling resources such as credit, work force, family labor and time which is required to manage any specific economic activity, presence of socio-cultural hurdles to women's participation in economic activities and lack of commitment within the communal sphere for activity managed by women (Tiwari, 2007). 


\section{Methodology}

For the social research different trends should be considered. Every good research project should have criteria which must be followed during the development of methodology till the completion of the research. At the same time this research takes into account factors that hinder alterations and seizes the onward movement. Marcia Westkott (1983), an American Sociologist, describes action research, making an argument that a good research, when involving women's lives, should be for women rather than about women (Westkott, M., 1983).

The paradigm of research depends upon the facts and theories. The theories and facts of the research topic are notions on which the researcher's describes his aim. The topic was selected this topic by observing the depriving conditions of the self employed women not only in Karachi but also in the third World. These women have been exploited in many ways. Their work has not been given any recognition since ages.

The woman entrepreneur of this study is located in the traditional, lower and lower middle class stratum of the Pakistani urban society in which she suffers or has suffered from restrictions on her mobility and freedom.

In Karachi size of the population of women entrepreneurs as defined for this study was not known.

For this study the sample size of 1800 self employed women was determined for useful statistical manipulations. The following 18 towns were selected to collect the sample: Keamari, SITE, Baldia, Orangi, Lyari, Saddar, Jamshed, Gulshan, Shah Faisal, Landhi, Korangi, North Nazimabad, New Karachi, Gulberg, Liaquatabad, Malir, Bin Qasim, Gadap.

For this study, it was decided to employ the survey methods. In this study, 1800 interviews were undertaken. Each interview was taken by spending couple of days in an interviewee house. The interviews were supported by pictures of the self employed women working according to the typologies of different work.

The interviewing schedule created for this research included questions that aimed at obtaining personal data about the respondents, such as age, educational attainment, marital status, number of children, typology of work, etc.

The data were congregated through a survey. For this research, researcher used investigatory methods to collect the required information. Data was collected with the 
help of interviewing schedule. The primary data was collected through a household model survey. The questionnaire based interview method was used.

After the data was completed, it was by hand fed into pre-prepared mannequin tables. The work was labour intensive, indeed. Lack of scientific equipment and absence of statistical soft ware were the major reasons for doing the work manually. Both qualitative and quantitative methods were used for the analysis of the data. Warily drawn tables and graphical interpretations are used to exhibit major findings of this research. The respond of questions provided by the respondents are interpreted in the light of the researcher's field observations.

\section{Conclusions}

The major findings of the research are that the majority of the respondents were found illiterate. It is predicted that poverty, low status, patriarchal norms, culture and delusion of religious traditions are the contributive factors. It is also evident that the majority of the heads of the household of the self employed women do not have permanent source of income. Majority of them belong to the nuclear family structure and the prediction could be drawn from the results that in some cases few children are forced to work because of extreme poverty. Interesting results were found that despite of poverty they somehow manage to have their own houses, out of 1800 respondents 1147 have owned their houses where as only 353 are living on rent. Those respondents who are living on rent are paying the rent up to Rs/1501-2500. All of the respondents have very low social and economical status and have very limited basic amenities of life. Statistics of the research shows that respondents are engaged in different income-generating activities but majority of them do not made any effort to upgrade their work by taking any skill development or vocational training courses, mostly women have learned skills from their neighbourhood women. Majority of the women (1625 out of 1800) began to work to have increased income for their families so that they could have a better life. Normally in societies like Pakistan women do not work until and unless there is an immense need for them to earn money. But still women carry heavy work load on their shoulders and the waged-work has acquired a permanent position in their lives; it might be because of poverty. Beside all their hectic routine these self employed women gave prime importance to their family along with their work. Majority of the respondents said that they were not satisfied with their work as they are.

Earning very low income and that the contractors for whom they were working didn't pay sufficient amount for their work. However, women feel no hesitation in doing work; this indicates the strong confidence level and sense of self-reliance among these women. Usually women feel proud to be the self employed women they feel themselves equal to men in the race of doing work or taking work load. Majority of the women (1288) said 
that due to work their status within the family has improved and they are now respected. Women work on all special occasions which indicate their dire need of earning money to eradicate or at least minimize poverty. Women needed mental peace and composure while working. It indicates the importance of mental and physical health of a woman while she is working. Majority of them go by self to purchase raw material for their work because they do not rely on others.

They also sold their goods in the market through the owner; indicating their contract base work. Whereas those who sold themselves it may be because they might not have some one to sell for them or either they do not trust anyone in this regard. Data also reflects that 1262 out of 1800 women have moderate level of knowledge about the value of their products. It indicates that these women could be deceived and duped when payment is made for their work. Women are normally paid after the good have been prepared as it's a normal pattern of business all over the world. They use to collect their payments themselves which is helpful in some to get the actual amount according to the value of the product. They normally are not happy what they are getting out of so strenuous work done because they realized and thought that this amount is not sufficient for their needs and due to high inflation rate they were also not able to save some amount from their monthly income for their hard times. It is clear from the data that money is badly needed for everyday need and therefore even education is not given a priority. Despite the fact that their earnings are not sufficient but still somehow women's income improved the life style of their family members. The results also indicate that self employed work is neglected by the society and these women workers are left to themselves neither an institution nor a generous person ever came to their rescue. This is a pathetic situation that these women are also being deprived of government assistance and even they do not get any zakat money from the fund. All of the respondents took loan from different people in case of extreme need but they found it very difficult to pay back their loan.

Women also stated that their work raise their status in the family has become better and they are respected more now. Neighbours and family members have respect for them and women come to them to seek their advice. Some women became more independent after their work became more successful. They also said that general atmosphere of the house has changed and got better work for women brought positive changes in their homes. Women feel that change has appeared in their overall life. By analyzing other categories as well it could be seen that work and income have supported them in all aspects of their lives.

Majority of the women (1371 out of 1800) knew that their health was affected by their work; this must be because of work pressure, malnutrition, and household work. Second highest majority group of 300 respondents are those women who found no mental peace in their lives because of their work but still they carry on their as if the stop working they 
have to face the callous attitude of their owner when they get ill. The responses show how these women are exploited by their owners even while they work for them during illness.

All of them want that their children gain education but their financial conditions didn't allow them to send their children to school. If any one of them manages the expenses then they prefer their son's to go to school rather than their daughters because sons are supposed to be the future investment they are supposed to be the bread winner.

All of the above given data indicates that these self employed women struggled really hard to maintain their confidence and respect. When asked about to seek any financial support they replied that they will take monetary support from any financial organization in order to improve their working conditions if that support will be given on easy terms. Regarding their future plans majority of them want to continue the same work they are doing.

\section{Summary}

The gender discrimination begins early in the lives of these women as there was absence of quality primary and secondary education, vocational training, ill-health, poverty, lack of vital knowledge about reproductive health etc.

Oxfam estimates that women work around 60 to 90 hours per week, and time use surveys reveal that across a selection of developing countries in Asia, Latin America and subSaharan Africa, women's working hours exceed those of men, often by a wide margin (Grown, 2005).

This story of women's economic empowerment is an account of great potential, all too often unfulfilled. It is not that women do not work; they often work longer hours than men - but they almost invariably earn less income as a result of their labors, decision making power and also because they own less property.

According to the UNICEF Report (2007)'Ensuring that women and men have equal opportunities to generate and manage income is an important step towards realizing women's right under the Convention on the Elimination of All forms of Discrimination against Women (CEDAW) and enhancing their development, self-esteem and influence both within society and in household' (UNICEF, 2006).

While there has been progressed in recent decades in engaging women in the self employed business sector but less attention has given on improving the conditions under which they are working. 
These self employed women whether living in rural or urban settings of Pakistan, in general, they work longer hours more than men also for the reason that they are running their self employment businesses from home. Some of them are having shops coupled with their homes, making designs on bangles, embroidery, cleaning chicken wings/claws, stitching/ embroidery work etc. All such typologies of work require their full involvement round the clock.

So in such cases their domestic and social lives affected drastically or in other words they might not spend any social life. Children are neglected when both parents are working out or inside the home and in the absence of any social support system, children rights to education, leisure, care and other responsibilities are at risk. The dilemma is also that the majority of the self employed women have no control over the businesses they have fostered in years and in cases when their husband dies or marriage breaks down, they have been excluded from owning property or assets.

Due to these flaws, self employed women face a lot of challenges in their business orientated careers like gender biases in employment sector, feminization of poverty, triple burden of work, freedom in mobility, lack of legal protection, lower wage, asset and earning gaps, childcare crisis in the formal sector (because when women work; children are neglected and sometimes they are not able to gain proper education).

Challenging attitudes toward self employed women's work required a multifaceted approach. Government of Pakistan should undertake legislative, financial and administrative measures in order to overcome these barriers. Need for Creating an enabling environment for women's entrepreneurship and participation in labor market is required for healing up the above mentioned challenges faced by these women.

Summarizing the discussion; researchers would like to advice that social policies should be promoted to tackle discrimination in the work place both at in and outside the home towards the self employed women and also to enable these women to reconcile their family responsibilities flawlessly with their businesses.

\section{Recommendations}

A brief synopsis of some of the suggested measures is presented below.

The vital role of education: For a girl child it is very important that she should have an equal access to education so when she enter in her professional life or take up any business, she would be having enough potential or knowledge in coping up different challenges. The education in Pakistan would become 'girls friendly' by taking up following measures. 
- Schools should adopt flexible scheduling.

- To allow married adolescents and unmarried parents to attend classes.

- Make school environment safe or immaculately gender equal in case when coeducational system is followed.

- Building separate girls schools close to katchi abadis and slum areas.

- Eliminating school fees would be helpful to ensure gender parity in education.

Eliminating gender inequalities in legislation: It is very important to eliminate gender discrimination in women's land and property rights. Following measures are suggested.

- Ensuring that women have opportunities and control over their house assets, land or property before or after marriage.

- Laws should be strictly followed and implemented in efforts to track violation against women in the matters of property rights.

- Bringing national laws in line with the international standards

The need for better data evaluation: In the light of this research it has been observed throughout the study that proper assessment of self employed women work lacks in Pakistan. Following measures should be taken up in this regard:

- The monthly monitoring of their work should be done by local agencies.

- The town mayors should provide full support to the national and international agencies working towards this task.

- Self employed women cells should be formed in every town by the fiscal support of government.

Women involvement in decision making: The government, international and national authorities should involve self employed women from all towns in policies at ground level. Their ideas would help in bringing change in their lives. Some key areas in this perspective are:

- Increase women's participation in national and local governments.

- Bring and groom women leaders from grass root level.

- Self employed women should be given a separate recognition at town level so that they can raise voice against their problems.

Improving the social lives of self employed women: As been discussed previously; that majority of these women have no social life due to the triple burden of work. It sometimes put them in the phase of mental and physical distortion. To bring betterment in their lives following measures should be taken.

- Their work should be given a yearly exposure at the national level so that they would become socialize and friendly.

- Fund raising concerts or theaters should be arranged; involving self employed women themselves so that it boost their confidence level.

- Counseling sessions should be done by government in order to communicate with the self employed women so that they may feel lighter expressing their views. 


\section{References}

Alan E: Kazdin. (1982). Single Case Research Design: Methods for clinical and Applied Settings, New York: Oxford University Press.

Ascertaining Impacts of Globalization on Rural Women in Pakistan: A Collaborative Research Study of South Asia Partnership-Pakistan and the Centre for Development Policy Alternatives, (2009).

Becker, Kristina Floodman, (2004). Fact Finding Study: The Informal Economy Stockholm, SIDA. $\mathrm{p}-11$.

Commission of the European Communities. Brussels, 21.11.2001. SEC (2001) 1900. Benchmarking Enterprise Policy: Results from the 2001 Scoreboard. http://europa.eu.int/comm/enterprise/ enterprise policy competitiveness/ doc/ sec_2001_1900_en.pdf $>$ Retrieved on 22 ${ }^{\text {nd }}$ June, 2010.

Franco, A. \& Winqvist, K. (2002). Statistics in focus. The entrepreneurial gap between Women and Men. Eurostat. http://epp.eurostat.cec.eu.int/cache/ITY OFFPUB/KSNK-02-011/EN/KS-NK-02-011-EN.PDF, http://www.eupreface.org/PDFs/ F\&F\% 20european \%20 level.pdf $>$ Retrieved on $22^{\text {nd }}$ June, 2010.

Grown, Caren, Geeta Rao Gupta \& Aslihan Kes, (2005). Taking Action: Achieving gender equality and empowering women, Earthscan, London/Virginia, for the UN Millennium Project Task Force on Education and Gender Equality, p, 77.

Home Net South Asian and Institute of Social Studies Trust (2006). Social Protection for Home Based Women Workers in South Asia: Learning from Action and Research New Delhi: ISST, p. 13.

Human Development Report (2004).

Humm, Maggie. (1989). The Dictionary of Feminist Theory, London: Prentice Hall, p. 313.

Hussain, Akmal, (2003) Poverty, Growth And Governance: Human Development Report', p, ix.

ILO (2002). Women and men in the informal economy: A statistical picture. Geneva, p, 44. Jason Cons and Kasia Paprocki of the Goldin Institute, 'The Limits of Microcredit-A Bangladeshi Case', Food First Backgrounder, Institute for Food and Development Policy, Winter 2008, volume 14, number 4. 
Lakwo, Alfred. (2006). Microfinance, Rural Livelihoods, And Women's Empowerment In Uganda, Leiden, African Studies Centre, p, 6

Linda, Mcdowell. (1999). Gender, Identity, And Place, University Of Minnesota Press, Minneapolis

Mammen, Kristin \& Christina, Paxon (2000). Women's Work and Economic Development, in The Journal of Economic Perspectives, Vol. 14, No. 4: pp, 141164.

Martha Chen in her introduction to Beyond Credit: A Conceptual framework' in her Beyond Credit: A Subsector Approach to Promoting Women's Enterprises, p, viii.

Mayoux, L. (2006). Women's Empowerment through Sustainable Micro-Finance: Rethinking “Best Practice, http://www.enterprise-impact.org.uk/pdf/ Women's Empowerment throughSustainableMicrofinance.pdf, Retrieved on $23^{\text {rd }}$ June, 2010.

Mernissi, Fatima (1991). The Veil and the Male Elite: A Feminist Interpretation of Women's Rights in Islam (tr. Mary JO Lakeland), New York: Addison-Wesley. P, 11.

Mohiuddin, Yasmeen Niaz. 'Health and Poverty: South Asia' in Encyclopedia of Women and Islamic Culture, vol. 3, p, 178.

Naqvi F., Zareen \& Shahnaz, Lubna (2002). How Do Women Decide To Work In Pakistan? Uses: $\quad$ http://www.pide.org.pk/pdf/psde $\% 2018$ agm/how $\% 20 \mathrm{do} \% 20$ women $\% 20$ decide $\% 20$ to $\% 20$ work $\% 20 \mathrm{in} \% 20$ pakis an.pdf, Retrieved on $8^{\text {th }}$ July, 2010.

Rassam, Amal (1984). 'Introduction: Arab Women --- The Status of Research in the Social Sciences and the Status of Women,' in Social Science Research and Women in the Arab World, Francis Printer/UNESCO, London, UK, pp, 1-3.

Salahuddin, Khaled and Ishrat Shamim, (1992). Women in Urban Informal Sector: Employment Pattern Activity Types Problems. Dhaka: Women for Women. P, 1.

Sen, Amartya (1999). Development as Freedom. New York: Anchor Books, p, xi.

Shaeed, Farida. \& Mumtaz, Khawar. (1990). Women's Economic Participation in Pakistan: A Status Report, Islamabad, UNICEF.

Siddiqui, Ahmad. Tasneem (2005). Dynamics of Social Change, Shadman Printers, Karachi, Pakistan, p, 143. 
Singh, Anupama (2008). Women Empowerment and Sustainable Development, Kanishka Publishers, Distributors, New Dehli, India, p, 38.

Sinha, Shalini (2006). Rights of Home based Workers. New Delhi: National Human Rights Commission of India, p, 14.

Situational Analysis of women in Pakistan- An Overview. Available at www.adb.org/ Documents/.../Women in Pakistan/chap 01.pdf $>$ Retrieved on $23^{\text {rd }}$ June, 2010.

Thomas R. Black. (2002). Understanding, Social Science Research, New Delhi, Sage Publications, p, 3

Tiwari, Sanjay \& Tiwari, Anshuja (2007). Women Entrepreneurship and Economic Development, Sarup \& Sons, New Dehli, India, p, 21.

UNICEF (2006). Calculations Based on Data Derived from United Nations Development Programme, Human Development Report 2006:Beyond scarcity: Power, poverty and the global water crisis, Oxford University Press for UNDP, New York, p, 379

UNIFEM (2009). Progress of the World Women, 2008-2009, p, 118.

Westkott, M. (1983). Women's Studies as a strategy for change: between criticism and vision', in G. B. Bowles and R. Duelli-Klein (eds.), Theories of Women's Studies, London: Routledge.

Dr. Nasreen Aslam Shah is Professor in the Department of Social Work \& Director of the Centre of Excellence for Women's Studies, University of Karachi.

Dr. Muhammad Nadeemullah is Assistant Professor in the Department of Social Work, University of Karachi.

Dr. Muhammad Faisal Zia is Research Associate in the Department of Social Work, University of Karachi.

Dr. Shamim Soomro is Associate Professor in the Department of Social Work, Sindh University, Jamshoro. 